\title{
Updated NGNP Fuel Acquisition Strategy
}

\author{
David Petti
}

Tim Abram

Richard Hobbins

Jim Kendall

The INL is a

U.S. Department of Energy

National Laboratory

operated by

Battelle Energy Alliance

December 2010
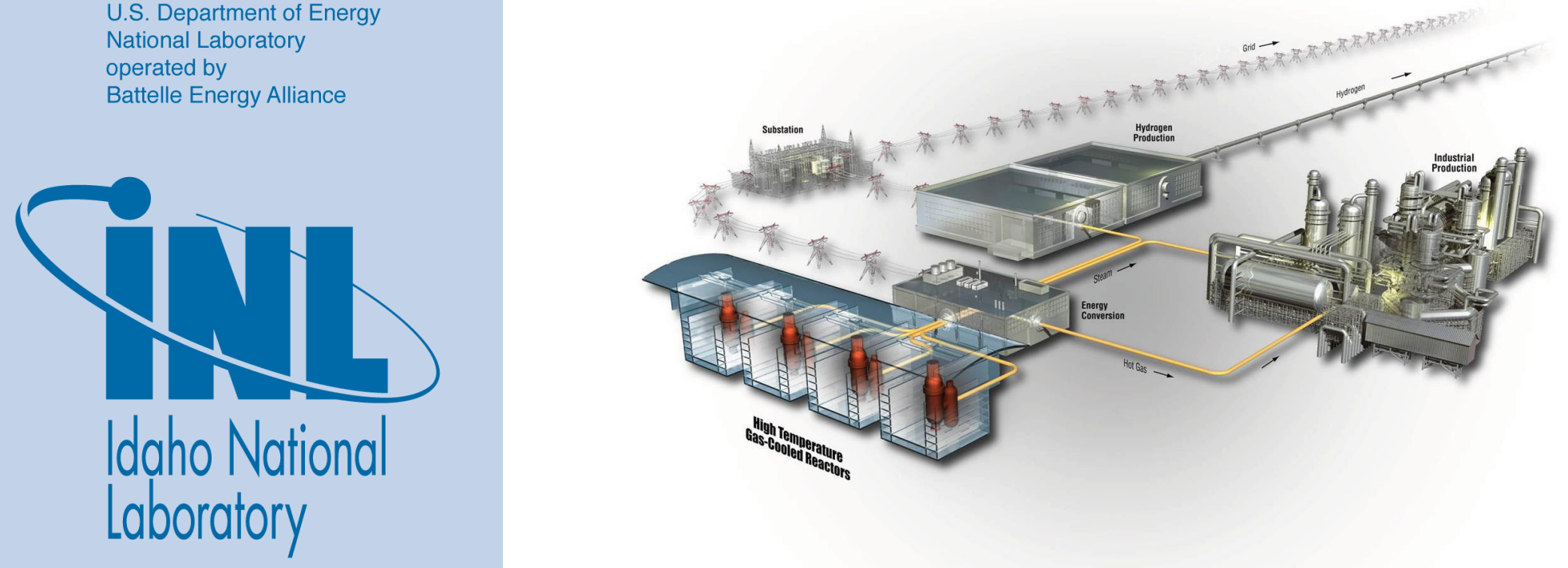


\section{DISCLAIMER}

This information was prepared as an account of work sponsored by an agency of the U.S. Government. Neither the U.S. Government nor any agency thereof, nor any of their employees, makes any warranty, expressed or implied, or assumes any legal liability or responsibility for the accuracy, completeness, or usefulness, of any information, apparatus, product, or process disclosed, or represents that its use would not infringe privately owned rights. References herein to any specific commercial product, process, or service by trade name, trade mark, manufacturer, or otherwise, does not necessarily constitute or imply its endorsement, recommendation, or favoring by the U.S. Government or any agency thereof. The views and opinions of authors expressed herein do not necessarily state or reflect those of the U.S. Government or any agency thereof. 
Rev. 2

\title{
Updated NGNP Fuel Acquisition Strategy
}

\author{
David Petti, Idaho National Laboratory \\ Tim Abram, University of Manchester \\ Richard Hobbins, RRH Consulting \\ Jim Kendall, Global Virtual LLC
}

December 2010

Idaho National Laboratory

Next Generation Nuclear Plant Project

Idaho Falls, Idaho 83415

Prepared for the

U.S. Department of Energy

Office of Nuclear Energy

Under DOE Idaho Operations Office

Contract DE-AC07-05ID14517 



\title{
Next Generation Nuclear Plant Project
}

\section{Updated NGNP Fuel Acquisition Strategy}

\author{
INL/EXT-07-12441 \\ Revision 2 \\ December 2010
}

Approved by:

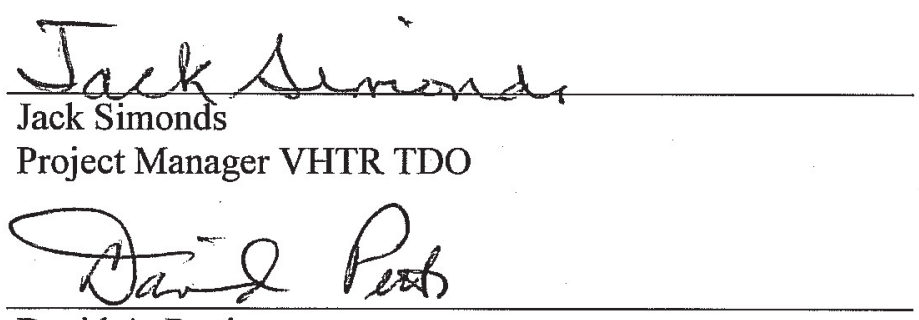

David A. Petti

VHTR TDO Director

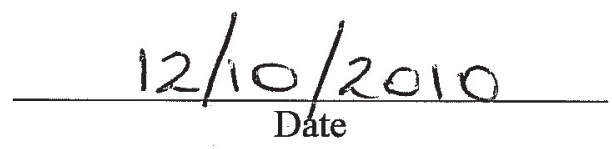

$12 / 10 / 2010$ 



\section{EXECUTIVE SUMMARY}

A Next Generation Nuclear Plant (NGNP) fuel acquisition strategy was first established in 2007. In that report, a detailed technical assessment of potential fuel vendors for the first core of NGNP was conducted by an independent group of international experts based on input from the three major reactor vendor teams. Part of the assessment included an evaluation of the credibility of each option, along with a cost and schedule to implement each strategy compared with the schedule and throughput needs of the NGNP project. While credible options were identified based on the conditions in place at the time, many changes in the assumptions underlying the strategy and in externalities that have occurred in the interim requiring that the options be re-evaluated. This document presents an update to that strategy based on current capabilities for fuel fabrication as well as fuel performance and qualification testing worldwide.

In light of the recent Pebble Bed Modular Reactor (PBMR) project closure, the Advanced Gas Reactor (AGR) fuel development and qualification program needs to support both pebble and prismatic options under the NGNP project. A number of assumptions were established that formed a context for the evaluation. Of these, the most important are:

- Based on logistics associated with the on-going engineering design activities, vendor teams would start preliminary design in October 2012 and complete in May 2014. A decision on reactor type will be made following preliminary design, with the decision process assumed to be completed in January 2015. Thus, no fuel decision (pebble or prismatic) will be made in the near term.

- Activities necessary for both pebble and prismatic fuel qualification will be conducted in parallel until a fuel form selection is made. As such, process development, fuel fabrication, irradiation, and testing for pebble and prismatic options should not negatively influence each other during the period prior to a decision on reactor type.

- Additional funding will be made available beginning in fiscal year (FY) 2012 to support pebble bed fuel fabrication process development and fuel testing while maintaining the prismatic fuel schedule.

Options for fuel fabrication for prismatic and pebble bed were evaluated based on the credibility of each option, along with a cost and schedule to implement each strategy. The sole prismatic option is Babcock and Wilcox (B\&W) producing uranium oxycarbide (UCO) tristructural-isotropic (TRISO) fuel particles in compacts. This option finishes in the middle of $2022^{\mathrm{a}}$. Options for the pebble bed are Nuclear Fuel Industries (NFI) in Japan producing uranium dioxide $\left(\mathrm{UO}_{2}\right)$ TRISO fuel particles, and/or $\mathrm{B} \& \mathrm{~W}$ producing $\mathrm{UCO}$ or $\mathrm{UO}_{2}$ TRISO fuel particles. All pebble options finish in mid to late 2022 .

In all cases the critical path is through the qualification testing, not the fabrication of first core given the limited testing capability available worldwide. Pebble options will rely on qualification activities in Europe (Petten and Institute for Transuranium Elements [ITU]) because these facilities provide the best cost and time effective approach given their broad experience with pebble testing activities.

The assessment revealed that significant increases in resources and manpower will be required to execute this strategy to support both pebble and prismatic fuel forms until a down selection is made. The cost of the pebble fuel qualification activities are estimated at $\$ 120 \mathrm{M}$, about $\$ 12 \mathrm{M}$ per year above the \$25-30M currently in the AGR program's budget baseline.

Based on this assessment the ranking of pebble options in order of preference is as follows:

- B\&W UCO TRISO because it leverages the significant effort expended already on UCO. It is less expensive than the other options, less disruptive to the overall program, and offers higher

\footnotetext{
${ }^{a}$ Finishes in this context means that the qualification is complete, topical reports are written, and the first core is fabricated.
} 
performance for the pebble bed because of the higher burnup achievable with UCO. The UCO options provides the most flexibility going forward since it appears to be an acceptable TRISO particle for both pebble and prismatic designs.

- $\quad \mathrm{B} \& \mathrm{~W} \mathrm{UO} \mathrm{U}_{2}$ TRISO because it requires about the same amount of fabrication development as the B\&W UCO TRISO option.

- $\quad \mathrm{NFI} \mathrm{UO} \mathrm{U}_{2}$ TRISO is the lowest priority because of the issues associated with using a foreign fuel vendor including export control, intellectual property (IP), and moderate risk associated with meeting the NGNP specification. Further, this option does not establish a viable U.S. fuel vendor. 


\section{CONTENTS}

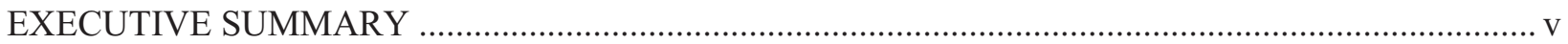

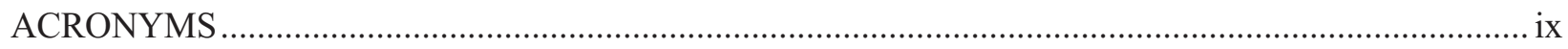

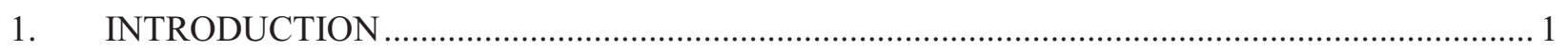

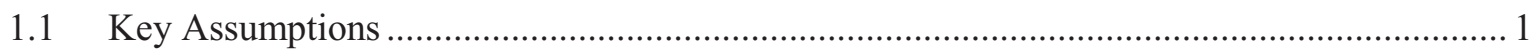

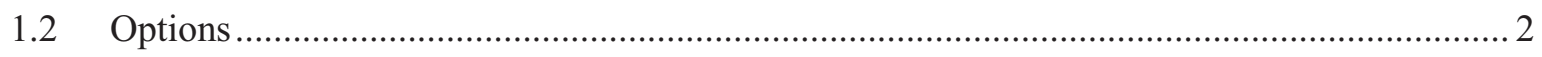

2. DESIGN AND PERFORMANCE CONSIDERATIONS …..................................................... 4

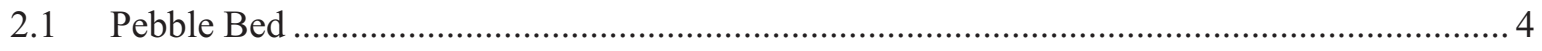

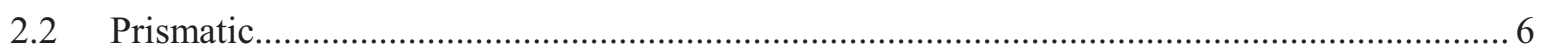

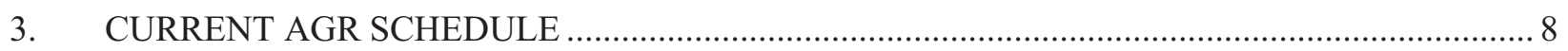

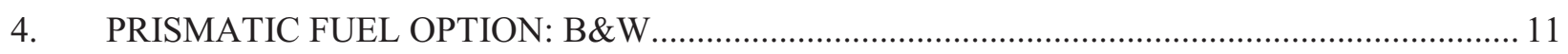

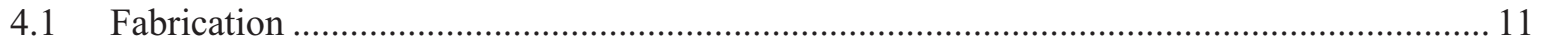

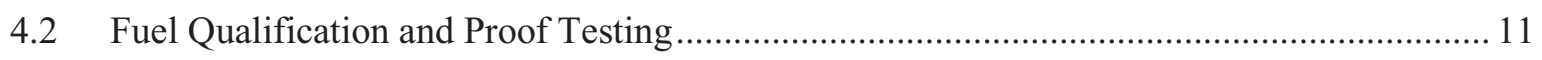

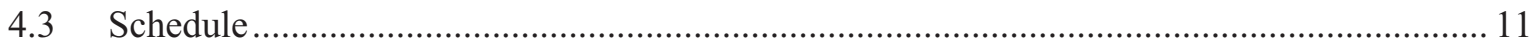

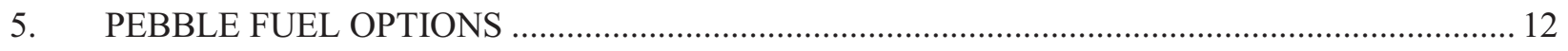

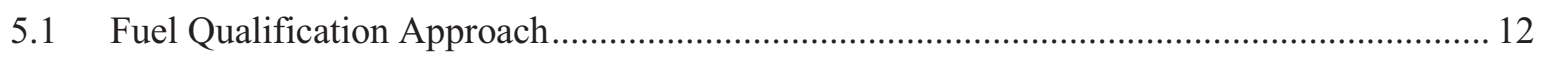

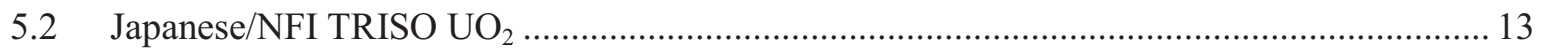

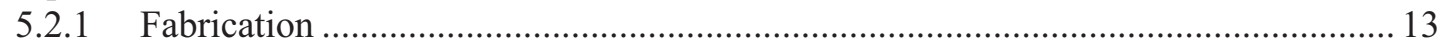

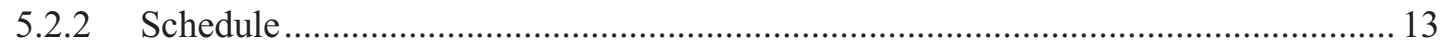

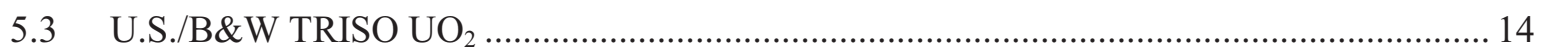

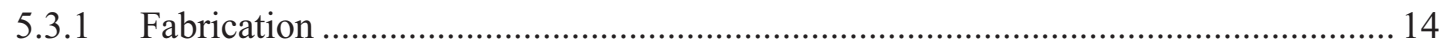

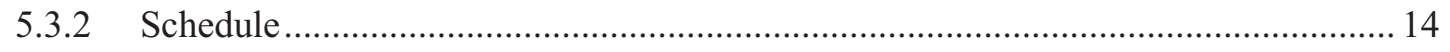

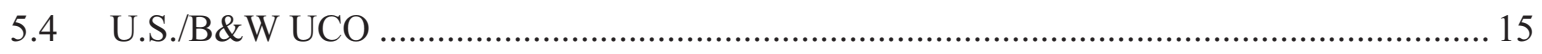

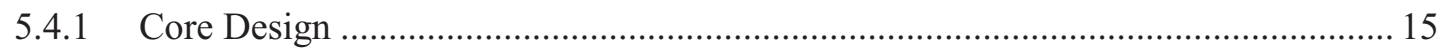

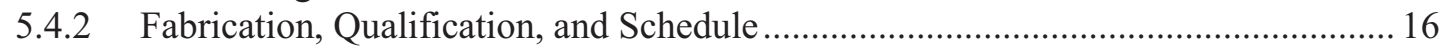

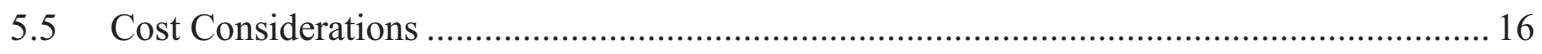

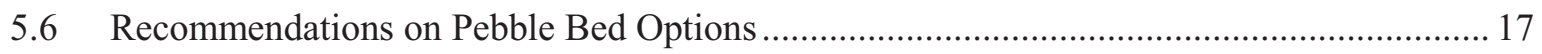

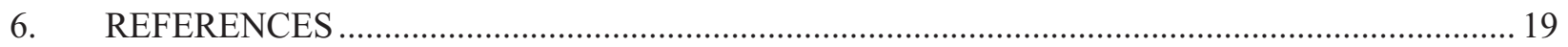

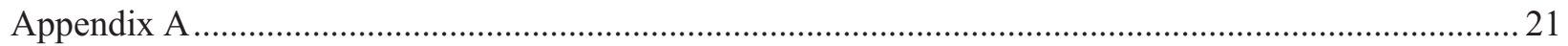




\section{FIGURES}

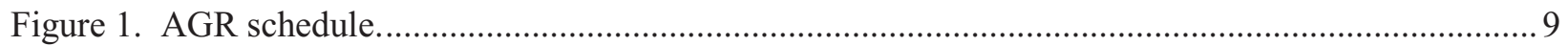

Figure 2. Schedule for B\&W prismatic fuel fabrication and qualification. ............................................ 11

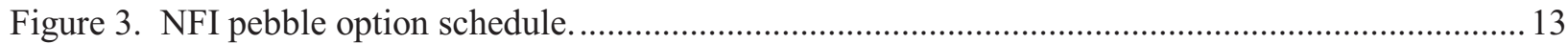

Figure 4. B\&W pebble option schedule in calendar years and quarters. .............................................. 15

\section{TABLES}

Table 1. Pebble bed fuel service conditions............................................................................................ 5

Table 2. NGNP pebble bed and HTR-Modul failure fraction values..................................................... 5

Table 3. Anticipated maximum service conditions for prismatic HTGR fuel for the NGNP.................... 6

Table 4. Preliminary prismatic HTGR fuel performance requirements................................................. 7

Table 5. Estimated additional cost to implement fuel qualification activities for either pebble

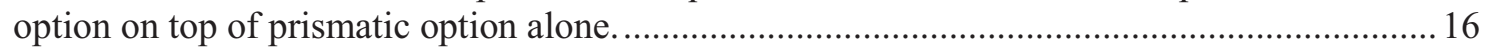

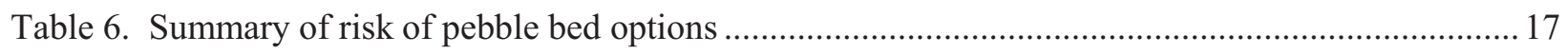

Table A-1. The relevant data from Table 13 and the calculational results are summarized below

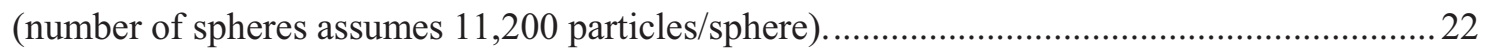

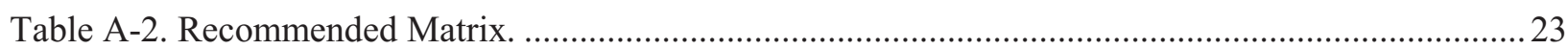




\section{ACRONYMS}

AGR Advanced Gas Reactor

ATR Advanced Test Reactor

AVR Arbeitsgemeinschaft Versuchsreaktor

B\&W Babcock and Wilcox

CEA Commissariat à l'énergie atomique

DOE Department of Energy

DOE-NE Department of Energy Office of Nuclear Energy

EFPDs effective full-power days

EU European Union

FIMA fissions per initial metal atom

FOA Financial Offer of Assistance

FY fiscal year

HEU highly enriched uranium

HFR High Flux Reactor

HTR High Temperature Reactor

HTR-PM High Temperature Reactor Pebble Bed Module

HTTR High Temperature Test Reactor

INET Institute of Nuclear and New Energy Technology

IP intellectual property

IPyC inner pyrocarbon

ITU Institute for Transuranium Elements

LEU low enriched uranium

MHTGR Modular High Temperature Gas-Cooled Reactor

MTR material test reactors

NEAC Nuclear Energy Advisory Committee

NESCA Nuclear Energy Corporation of South Africa

NFI Nuclear Fuel Industries

NRC Nuclear Regulatory Commission

OPyC outer pyrocarbon

ORNL Oak Ridge National Laboratory

PBMR Pebble Bed Modular Reactor

PIE post-irradiation examination

PyC pyrocarbon 
ROT reactor outlet temperature

$\mathrm{SiC}$ silicon carbide

TRISO tristructural-isotropic

UCO uranium oxycarbide

$\mathrm{UO}_{2} \quad$ uranium dioxide

$\mathrm{V} \& \mathrm{~V} \quad$ verification and validation 


\section{Updated NGNP Fuel Acquisition Strategy}

\section{INTRODUCTION}

A Next Generation Nuclear Plant (NGNP) fuel acquisition strategy was established in $2007 .{ }^{1}$ In that report, a detailed technical assessment of potential fuel vendors for the first core of NGNP was conducted by an independent group of international experts based on input from the three major reactor vendor teams. Part of the assessment included an evaluation of the credibility of each option, along with a cost and schedule to implement each strategy compared with the schedule and throughput needs of the NGNP project. While credible options were identified based on the conditions in place at the time, many changes in the assumptions underlying the strategy and in externalities that have occurred in the interim requiring that the options be re-evaluated. This document presents an update to that strategy based on current capabilities for fuel fabrication as well as fuel performance and qualification testing worldwide.

\subsection{Key Assumptions}

At the time of this writing, the Department of Energy (DOE) has entered into a Financial Offer of Assistance (FOA) with reactor vendor teams to execute the conceptual design of the NGNP (referred to as Phase I of the project). This activity is expected to be completed at the end of calendar year 2010. At the same time, the NGNP project is undergoing a formal review by DOE-Nuclear Energy's (NE) advisory committee (also known as the Nuclear Energy Advisory Committee [NEAC]) to assess the project's readiness to go forward into preliminary design (also known as Phase II). The Secretary of Energy is expected to make a decision on going forward into Phase II in June 2011. Based on this current situation and guidance from DOE, the following are key assumptions for our assessment:

- DOE Secretary Chu recommends that the NGNP project go forward to Phase II in June 2011. A second FOA (or similar procurement vehicle) for Phase II activities is issued no later than September 2011 and vendor team selection(s) made by September 2012. Vendor teams would start preliminary design in October 2012 and complete in May 2014. (Twenty months for preliminary design).

- A decision on reactor type will be made following preliminary design, with the decision process assumed to be completed in January 2015. Thus, no fuel decision (pebble or prismatic) will be made in the near term.

- In light of the recent Pebble Bed Modular Reactor (PBMR) project closure ${ }^{\mathrm{b}}$, the Advanced Gas Reactor (AGR) fuel development and qualification program needs to support both pebble and prismatic options.

- Reactor configuration and power level are still unknown. The starting points for this assessment will be adjusted versions of the High Temperature Reactor (HTR)-Modul and Modular High Temperature Gas-Cooled Reactor (MHTGR) for pebble and prismatic designs as presented in the recent Nuclear Regulatory Commission (NRC) fuel qualification white paper. ${ }^{2}$

- The AGR program continues to support the prismatic-option-based schedule given in Section 3. A critical aspect of this schedule is the completion of the AGR-5/6 irradiation prior to the start of the Advanced Test Reactor (ATR) core internals change out (CIC) presently planned for 2015 (currently scheduled to last from February and August 2015). If this objective is not met, the prismatic schedule will be delayed a minimum of two years, and access to the ATR northeast flux trap for AGR-5/6 and subsequent AGR irradiations may be lost because of high demand for irradiation positions in ATR.

b. Address by the Minister of Public Enterprises of the Republic of South Africa to the National Assembly, September 16, 2010. 
- Activities necessary for both pebble and prismatic fuel qualification will be conducted in parallel until a fuel form is selected.

- Process development, fuel fabrication, irradiation, and testing for pebble and prismatic options should not negatively influence each other during the period prior to a decision on reactor type.

- The approach to pebble fuel qualification is based on the PBMR approach of establishing and validating by experiment a failure fraction versus temperature curve and using that curve to predict particle failures in the design/safety analysis. However, because replication of the German fuel design, fabrication process, and equipment, as planned for the PBMR approach, will not be followed, additional testing will be required to qualify the fuel.

- For prismatic fuel, the approach is to demonstrate failure fractions with statistically significant quantities of fuel, but the extrapolation to fuel performance in the core is done via computer codes. Thus, there is a need for verification and validation $(\mathrm{V} \& \mathrm{~V})$ of these codes as part of the fuel qualification effort.

- The ATR North East flux trap is occupied for the prismatic option. No other irradiation locations are available at ATR that can accommodate a pebble. Therefore, pebble qualification will need to be done in Europe. There is strong justification for this approach given the broad European Union (EU) experience in the area and the current project schedule.

- Moisture and air ingress testing will be required for both options.

- Additional funding will be made available beginning in fiscal year (FY) 2012 to support pebble bed fuel fabrication process development and fuel testing while maintaining the prismatic fuel schedule.

\subsection{Options}

Four potential tristructural-isotropic (TRISO) fuel fabrication organizations exist worldwide:

- AREVA/Commissariat à l'énergie atomique (CEA) in France

- Institute of Nuclear and New Energy Technology (INET)/Northern Nuclear Fuel Company in China

- Nuclear Fuel Industries (NFI) in Japan

- $\quad$ Babcock \&Wilcox $(B \& W)$ in the U.S.

PBMR/Nuclear Energy Corporation of South Africa (NECSA) in South Africa had plans to develop a pebble fuel fabrication facility and hence was a primary option; however, it was recently announced that the PBMR organization would be placed in a "care and maintenance mode" and the Fuel Development Laboratory on the NECSA premises will be decommissioned. Thus, they are no longer a viable option. Considerations regarding the four options listed above are summarized below:

- The AREVA/CEA capability to make TRISO uranium dioxide $\left(\mathrm{UO}_{2}\right)$ compacts is at laboratory scale, with recent activities limited to fabrication of compacts for irradiation in AGR-2. Fabrication of fuel for the NGNP would require a major program for scale-up of kernel production, coaters, and compacting equipment (for prismatic fuel) or development of sphere production capability (for pebble fuel). Thus, AREVA/CEA is not considered an option going forward.

- China has a pilot line capability at INET that was used to make fuel for the first core load of HTR-10, the 10-MW pebble bed at Tsinghua University. China plans construction of a pilot fuel production plant by Northern Nuclear Fuel Company in order to achieve the throughput needed to support the High Temperature Reactor Pebble-bed Module (HTR-PM) reactor project. As of this writing, that project is on hold pending the Chinese government's decision to continue with the pebble bed technology. Given this uncertainty in the HTR-PM project, and complex issues including 
international agreements, intellectual property (IP) ownership, shipping, etc., this is not considered a viable option for NGNP.

- Westinghouse and NFI are both owned by Toshiba (Japan), with Westinghouse recommending NFI as a potential supplier of pebble fuel. NFI fabricated $\mathrm{UO}_{2}$ TRISO particles of a design similar to the German particles in annular compact form for the High Temperature Test Reactor (HTTR) first core.

- The NGNP/AGR program has been working to establish B\&W as a U.S. vendor for prismatic uranium oxycarbide (UCO) TRISO particle fuel in compacts. In addition, $\mathrm{B} \& \mathrm{~W}$ has fabricated $\mathrm{UO}_{2}$ TRISO particles generally consistent with the German particle specifications for irradiation in AGR-2.

Thus, B\&W in the U.S. and NFI in Japan are considered the only two credible vendors for the NGNP first core. For the prismatic option, B\&W is considered the only viable vendor, as discussed in Section 4. For the pebble bed, three options are under consideration: NFI fabricating $\mathrm{UO}_{2}$ TRISO pebbles, $\mathrm{B} \& \mathrm{~W}$ fabricating $\mathrm{UO}_{2}$ TRISO pebbles, and $\mathrm{B} \& \mathrm{~W}$ fabricating UCO TRISO pebbles. These options are discussed in more detail in Section 5. 


\section{DESIGN AND PERFORMANCE CONSIDERATIONS}

The reference particle for both pebble and prismatic fuel consists of a $\mathrm{UO}_{2}$ or $\mathrm{UCO}$ microsphere (kernel) coated with multiple layers of pyrocarbon (PyC) and silicon carbide ( $\mathrm{SiC}$ ). UCO is a mixture of $\mathrm{UO}_{2}$ and uranium carbides (UC and $\mathrm{UC}_{2}$ ). The buffer, inner pyrocarbon (IPyC), SiC, and outer pyrocarbon $(\mathrm{OPyC})$ layers are referred to collectively as a TRISO coating. The coating system constitutes a miniature pressure vessel that provides containment of the radionuclides (condensed phase and gases) generated by fission of the nuclear material in the kernel. Although pebble and prismatic HTGR designs for NGNP are still evolving, the most recent reactor service conditions and fuel performance requirements have been discussed with the NRC and will be used as the baseline for this work.

\subsection{Pebble Bed}

The pebble bed design is an HTGR employing online fueling. The pebble bed plant concept described herein is still in conceptual design and is, therefore, subject to change as the initial design decisions are verified. However, the starting point for the reactor core design is based on the German HTR-Modul design with the power increased from 200 to $250 \mathrm{MWt}$, core height increased from 9.4 to $10.5 \mathrm{~m}$, and reactor coolant outlet temperature increased from 700 to $750^{\circ} \mathrm{C}$.

The reactor conditions described here are for the purpose of identifying an operational envelope for the fuel assuming that the reactor is operating at a mixed-mean coolant outlet temperature of $750^{\circ} \mathrm{C}$ (reactor outlet temperature [ROT]) and power level of $250 \mathrm{MWt}$.

Two particle options are under consideration for the pebble fuel:

1. Based on German low enriched uranium (LEU) $\mathrm{UO}_{2}$ TRISO fuel particles as developed for the HTR Modul Reactor. German LEU TRISO fuel was used in the Arbeitsgemeinschaft Versuchsreaktor (AVR) and irradiated in three material test reactors (MTRs), showing, a high level of as-fabricated quality, and excellent performance under irradiation and in post-irradiation testing.

2. LEU UCO TRISO particles as developed by the U.S. AGR program also showing a high level of asmanufactured quality and excellent performance under irradiation (post-irradiation testing of fuel from the first irradiation [AGR-1]) will begin in FY 2011).

Both particle options would be fabricated into spheres based on the German sphere design. The fuel spheres are contained in a tall cylindrical core volume shaped and supported by the reflectors of the core structure.

The fuel service conditions described here are derived from an equilibrium core of fuel spheres containing Option 1 particles, each containing $7 \mathrm{~g}$ of $\mathrm{UO}_{2}$, whose ${ }^{235} \mathrm{U}$ enrichment is $7.8 \%$. The pebble bed reactor with Option 1 fuel would be started up with fuel also containing $7 \mathrm{~g}$ of $\mathrm{UO}_{2}$, but enriched to approximately 4.2 to $4.5 \%{ }^{\mathrm{c}}{ }^{235} \mathrm{U}$ to control start-up reactivity; it would then be transitioned to the use of equilibrium fuel. Pebble-bed fuel service conditions are listed in Table 1. Additional analysis is required to determine service conditions for the Option 2 particles (see Section 5.4), but the conditions are expected to be similar to those discussed below.

c. The enrichment of the start-up fuel is expected to be in this range, with a final determination to be made following more detailed analysis of the startup and initial operation of the core. 
Table 1. Pebble bed fuel service conditions. ${ }^{\mathrm{d}}$

\begin{tabular}{ccc}
\hline \multicolumn{1}{c}{ Parameter } & Core Average Value & Maximum Value \\
\hline \multicolumn{3}{c}{ Normal Operation } \\
Discharge Burnup, $\%$ fissions per initial metal atom (FIMA) & 8.31 & 8.75 \\
Discharge Fast Fluence, $10^{21} \mathrm{n} / \mathrm{cm}^{2}(\mathrm{E}>0.1 \mathrm{MeV})$ & 2.01 & 2.39 \\
Sphere Center Temperature, ${ }^{\circ} \mathrm{C}$ & 644 & 1,048 \\
Accident Conditions - Best Estimate Maximum Transient Conditions & \\
Sphere Temperature, ${ }^{\circ} \mathrm{C}$ & 970 & 1,483 \\
\hline
\end{tabular}

HTGRs' high degree of safety results from the ability of coated particles in the fuel to retain fission products at their site of origin, even at high temperatures. For fresh fuel, the maximum allowed amount of free uranium in a fuel sphere is a specified characteristic known as the "free-uranium fraction." The free-uranium fraction consists of enriched uranium contained in coated particles that have defective $\mathrm{SiC}$ layers (with or without defective PyC layers), enriched uranium on the outer surfaces of coated particles due to contamination in the coater during the coating process, and natural uranium contained in natural graphite, which is the main component of the matrix graphite body of a fuel sphere. The free-uranium fraction for as-manufactured fuel is determined by the burn-leach procedure performed on spheres. Consistent with the German program's conservative assessment of their manufacturing data, the value of $6 \times 10^{-5}$ for a single fuel lot will be used as the design value for the free-uranium fraction.

As uranium in the kernels of coated particles in fuel spheres is fissioned in the reactor core, failure of a small fraction of coated particles might occur due to an increase in pressure within coated particles as a result of the accumulation of gaseous fission products within intact coating layers. Failure of an additional small fraction of coated particles might occur when coated particles are heated during a core heat-up accident due to an increase in internal pressure resulting from an increase in temperature.

The number of failed coated particles present in a fuel sphere at any time is expressed as the failed coated-particle fraction, abbreviated to "failure fraction," which is the number of failed coated particles in a fuel sphere relative to the total number of coated particles in the sphere. Typical values of failure fractions under normal and accident conditions based on German irradiation and heat-up testing experience are shown in Table 2.

Table 2. NGNP pebble bed and HTR-Modul failure fraction values.

\begin{tabular}{ccccc}
\hline Temperature $\left({ }^{\circ} \mathrm{C}\right)$ & NGNP Expected & $\begin{array}{c}\text { NGNP 95\% } \\
\text { Confidence }\end{array}$ & NGNP Design & Modul Design \\
\hline 800 & $1.44 \times 10^{-5}$ & $4.88 \times 10^{-5}$ & $1.06 \times 10^{-4}$ & $1.6 \times 10^{-4}$ \\
1,200 & $1.44 \times 10^{-5}$ & $4.88 \times 10^{-5}$ & $1.06 \times 10^{-4}$ & $1.6 \times 10^{-4}$ \\
1,600 & $2.08 \times 10^{-4}$ & $4.11 \times 10^{-4}$ & $5.04 \times 10^{-4}$ & $6.6 \times 10^{-4}$ \\
1,700 & $6.12 \times 10^{-4}$ & $9.31 \times 10^{-4}$ & $1.04 \times 10^{-3}$ & - \\
1,800 & $1.85 \times 10^{-3}$ & $2.21 \times 10^{-3}$ & $2.33 \times 10^{-3}$ & - \\
\hline
\end{tabular}

d. The core average and maximum discharge burnup and fast fluence values include the effects of variations resulting from uncertainties in the burnup measurement system and trajectory-dependent variations in burnup and fluence accrual in the last cycle of a pebble before it is discharged by the fuel handling system. 


\subsection{Prismatic}

The prismatic HTGR concept is a high temperature, gas-cooled, graphite-moderated reactor utilizing a prismatic graphite block fuel form. In this design, hexagonal graphite fuel blocks are used, each containing TRISO fuel particles bonded together within a carbonaceous matrix material to form cylindrical fuel compacts. This concept results in a fixed-core configuration that requires periodic refueling.

The NGNP prismatic reactor concept is in the beginning stages of conceptual design. The point of departure for the conceptual design is the 350-MWth MHTGR design modified to replace the fissile/fertile particle system with a single particle of intermediate enrichment. The fuel type selected by the U.S. prismatic HTGR program is LEU UCO TRISO, selected primarily because of its ability to perform well at relatively high fuel burnup, which significantly improves the economics of prismatic HTGRs.

Table 3 summarizes the anticipated maximum service conditions, including accidents, for prismatic HTGR-based fuel where it is assumed that a single UCO fuel particle system is used with a $425-\mu \mathrm{m}$-diameter kernel of 14\% enrichment. These values are intended to be design guidelines.

Table 3. Anticipated maximum service conditions for prismatic HTGR fuel for the NGNP.

\begin{tabular}{lc}
\hline \multicolumn{1}{c}{ Parameter } & Maximum Value \\
\hline Fuel temperature - normal operation, ${ }^{\circ} \mathrm{C}$ & 1,400 \\
Time-averaged fuel temperature, ${ }^{\circ} \mathrm{C}$ & 1,250 \\
Fuel temperature (accident conditions), ${ }^{\circ} \mathrm{C}$ & 1,600 \\
Fuel burnup, $\%$ FIMA & $17^{\mathrm{a}}$ \\
Fast fluence, $10^{25} \mathrm{n} / \mathrm{m}^{2}(\mathrm{E}>0.18 \mathrm{MeV})$ & 5 \\
\hline a. $\quad$ Estimated value for $14 \%$ enriched $425-\mu \mathrm{m}$ reference fuel particle. & \\
\hline
\end{tabular}

The preliminary as-manufactured fuel quality requirements and in-service performance requirements for prismatic HTGR fuel for the NGNP are given in Table 4. The requirements for in-service performance are specified on a core-average basis. The requirements for as-manufactured fuel quality and in-service fuel performance are based on a two-tier set of radionuclide design criteria (allowable core release rates), referred to as the "Design" and "Maximum Expected" criteria. The "Design" criteria represent upper limits for all normal operating conditions and any off-normal events expected to occur during plant operation. The "Design" criteria account for uncertainties in the design methods and supporting data and represent a design margin over the "Maximum Expected" criteria, which are used for applications where "best-estimate" results are appropriate, including developing component-removal and maintenance procedures. The fuel and reactor core are to be designed, fabricated, and operated such that there is at least a $50 \%$ probability that the contamination, defective particle, and failed particle fractions will be less than the "Maximum Expected" criteria, and at least a 95\% probability that the releases will be less than the "Design" criteria. 
Table 4. Preliminary prismatic HTGR fuel performance requirements.

\begin{tabular}{lcc}
\hline \multicolumn{1}{c}{ Parameter } & \multicolumn{2}{c}{ NGNP $-750^{\circ} \mathrm{C}$ Core Outlet Temperature } \\
Maximum Expected & Design \\
\hline As-Manufactured Fuel Quality & \\
HM contamination & $\leq 1.0 \times 10^{-5}$ & $\leq 2.0 \times 10^{-5}$ \\
Missing or defective buffer & $\leq 1.0 \times 10^{-5}$ & $\leq 2.0 \times 10^{-5}$ \\
Missing or defective IPyC & $\leq 4.0 \times 10^{-5}$ & $\leq 1.0 \times 10^{-4}$ \\
Defective SiC & $\leq 5.0 \times 10^{-5}$ & $\leq 1.0 \times 10^{-4}$ \\
Missing or defective OPyC & 0.01 & 0.02 \\
& In-Service Fuel Failure & \\
Normal operation & $\leq 5.0 \times 10^{-5}$ & $\leq 2.0 \times 10^{-4}$ \\
Core heat-up accidents & $\leq 1.5 \times 10^{-4}$ & $\leq 6.0 \times 10^{-4}$ \\
\hline
\end{tabular}




\section{CURRENT AGR SCHEDULE}

The current AGR schedule ${ }^{3}$, which addresses the full scope of activities for qualification of fuel for a prismatic design, is shown in Figure 1. The formal qualification testing consists of the AGR-5/6 irradiation and the follow-on heat-up tests. Activities related to AGR-7 and -8 are necessary to verify and validate the fuel performance and fission-product transport codes used by the prismatic vendors in their design and safety analysis. The critical path early in the program is through the irradiations (AGR-2, AGR-3/4, and AGR-5/6). However, in the later years, the post-irradiation examination (PIE), especially establishing a capability to test for moisture, establishing an out-of-pile fission-product-transport test loop, and conducting the requisite experiments in that loop become key critical path items.

The schedule for irradiation testing completes in March 2017, and PIE and safety testing associated with AGR-7 and -8 complete by September 2019. The fission-product transport activities, consisting of tests to study the transport of fission products in the primary system and the reactor building, are generic for both concepts and under any of the options presented here will continue through mid-year 2022.

An important constraint and pacing schedule item in the current AGR program is the irradiation testing. The use of the ATR Northeast Flux Trap allows the program to complete each irradiation in about 18 months compared to the approximate 2.5-year duration for AGR-1 and AGR-2 in large B positions in the ATR reflector. The irradiation tests are back to back in the schedule. A major outage is anticipated in the ATR in mid 2015 to change out the core internals. AGR-5/6 must be completed prior to this major outage. Any experiments in the reactor at that time will be removed and re-inserted after the outage. The re-insertion poses a major technical risk to the program because of the potential loss of active instrumentation in the experiment. Thus, in the near term, activities related to achieving AGR-5/6 insertion have the highest priority to hold the schedule. Furthermore, if the AGR program cannot maintain the schedule and the flux trap becomes open for a few months, there is a high risk of losing the irradiation position to other programs given the high demand for irradiation experiments in the ATR.

The availability of the ATR and U.S. PIE facilities to perform some of the pebble fuel qualification scope depends largely on when the reactor design (pebble or prismatic) decision is made. If the pebble bed option is chosen by February 2014 (right before the end of preliminary design), AGR-7/8 would not occur and there would be enough time to design and build a pebble test train for use in the ATR once the core internals change out is completed in August 2015. Then the work scope outlined for the pebble options in Section 4 could be accelerated by concurrently performing half of the work in the U.S. and half of the work in the EU facilities. However, given the uncertainty associated with the schedules for completion of preliminary design, establishment of a public/private partnership, and selection of a reactor concept, it is prudent to assume full independent schedule paths for qualification at this time. If schedules for preliminary design and reactor selection accelerate such that a decision could be made in early 2014, this option can be re-examined at that time. 
AGR-1 - Shakedown Small Coater Fuel (Large B) 10/1/03 4/23/13

AGR-1 Fuel Fabrication

$10 / 1 / 03 \quad 9 / 29 / 06$

AGR-1 Design and Assembly

10/1/03 12/22/06

AGR-1 Irradiation

$12 / 25 / 06 \quad 11 / 20 / 09$

AGR-1 PIE and Safety Testing

$11 / 23 / 09 \quad 11 / 6 / 12$

AGR-1 Data Analysis and Reporting

$10 / 1 / 03 \quad 4 / 23 / 13$

$\square$ AGR-1 Fuel Fabrication
$\square$ AGR-1 Design and Assembly
$\square$ AGR-1 Irradiation

\section{AGR-2 Production Scale Fuel Performance} (Large B)

10/2/06 $10 / 4 / 16$

AGR-2 Fuel Fabrication $\quad 10 / 2 / 06 \quad 4 / 9 / 10$

AGR-2 Design and Assembly

$5 / 5 / 08 \quad 6 / 11 / 10$

AGR-2 Irradiation (Large B)

$6 / 23 / 10 \quad 3 / 26 / 13$

AGR-2 PIE and Safety Testing

$3 / 27 / 13 \quad 4 / 19 / 16$

$\square$ AGR-1 PIE

AGR-2 Data Analysis and Reporting

$10 / 2 / 06 \quad 10 / 4 / 16$

AGR-1 Data Analysis and Reporting

AGR-3/4 Fission Product Transport Data (NE Flux Trap)

$5 / 8 / 06 \quad 11 / 7 / 16$

AGR-3/4 Fuel Fabrication 5/8/06 3/14/11

AGR-3/4 Design and Assembly

$3 / 2 / 09 \quad 7 / 11 / 11$

AGR-3/4 Irradiation

10/4/11 4/29/13

AGR-3/4 PIE and Safety Testing

$4 / 30 / 13 \quad 5 / 25 / 16$

AGR-3/4 Data Analysis and Reporting

$5 / 8 / 06 \quad 11 / 17 / 16$

AGR-5/6 Fuel Qualification (Flux Trap) $\quad$ 10/1/08 6/21/18

AGR-5/6 Fuel Fabrication $\quad 10 / 1 / 08 \quad 1 / 24 / 13$

AGR-5/6 Design and Assembly

$10 / 13 / 10 \quad 6 / 20 / 13$

AGR-5/6 Irradiation $\quad 6 / 21 / 13 \quad 1 / 15 / 15$

AGR-5/6 PIE and Safety Testing

$1 / 16 / 1512 / 22 / 17$

AGR-5/6 Data Analysis and Reporting $\quad$ 10/1/08 6/21/18

AGR-7/8 Fuel Performance and Fission Product Transport V\&V (Flux Trap)

\begin{tabular}{lrr}
\hline AGR-7/8 Fuel Fabrication & $8 / 1 / 12$ & $1 / 30 / 13$ \\
\hline AGR-7/8 Design and Assembly & $7 / 2 / 12$ & $6 / 14 / 13$ \\
\hline ATR Core Internal Changeout & $2 / 1 / 15$ & $8 / 1 / 15$ \\
\hline AGR-7/8 Irradiation & $8 / 10 / 15$ & $3 / 3 / 17$ \\
\hline AGR-7/8 PIE and Safety Testing & $3 / 6 / 17$ & $9 / 6 / 19$ \\
\hline AGR-7/8 Data Analysis Reporting & $8 / 1 / 12$ & $9 / 4 / 20$
\end{tabular}

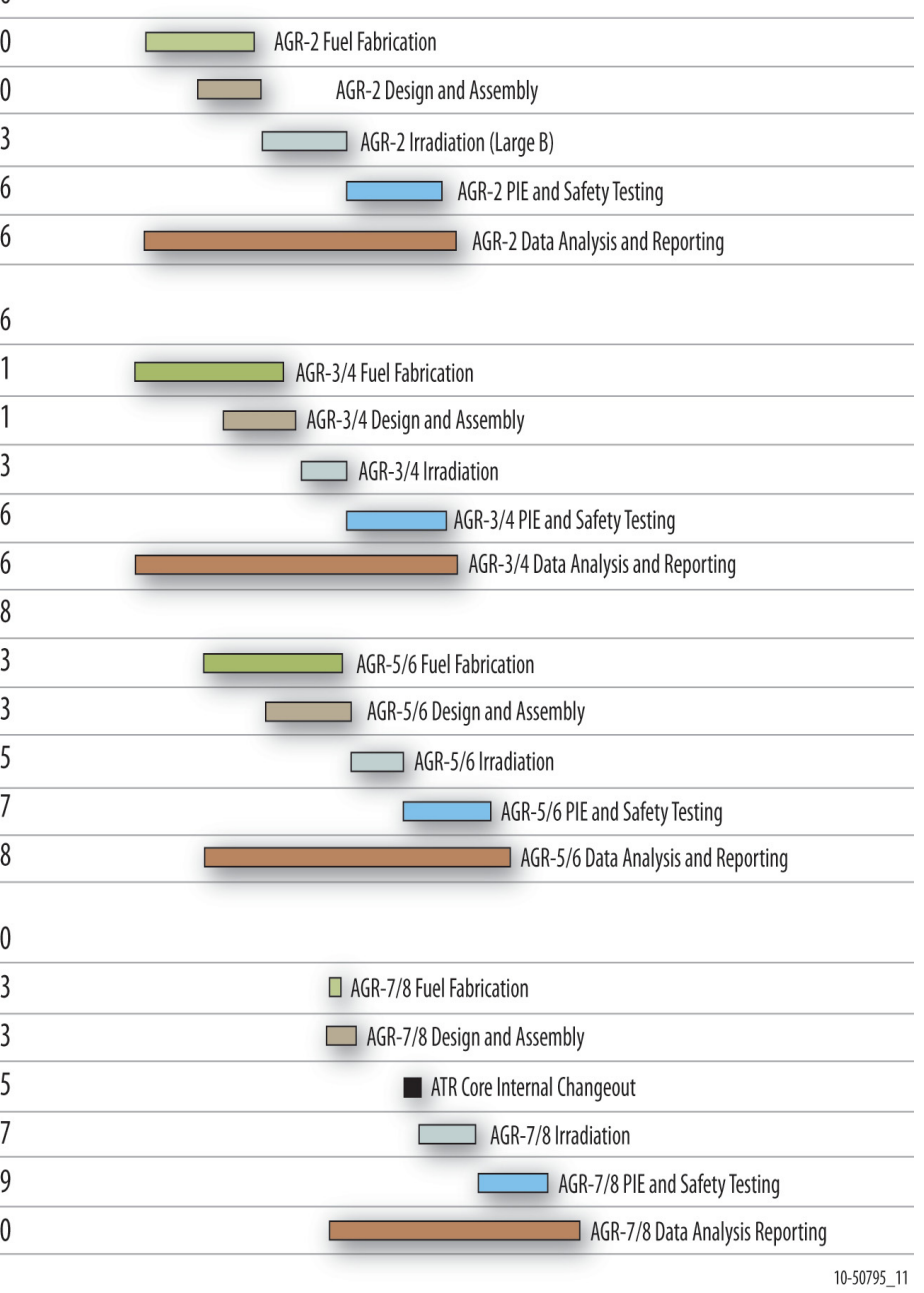

Figure 1. AGR schedule. 


\begin{tabular}{|c|c|c|}
\hline FUEL DEVELOPMENT AND QUALIFICATION & $10 / 1 / 03 \quad 9 / 4 / 20$ & \\
\hline Fuel Performance Modeling & $9 / 30 / 03 \quad 2 / 6 / 19$ & I Fuel Performance Modeling \\
\hline ZrC Modeling & 10/1/07 9/30/13 & $\square$ ZrCModeling \\
\hline PyC Modeling & $10 / 1 / 07 \quad 8 / 22 / 14$ & $\square$ Pyc Modeling \\
\hline AGR-1 Modeling & $9 / 30 / 03 \quad 2 / 15 / 11$ & $\square$ AGR-1 Modeling \\
\hline AGR-2 Modeling & $3 / 26 / 10 \quad 6 / 18 / 13$ & $\square$ AGR-2 Modeling \\
\hline AGR-3/4 Modeling & $3 / 2 / 09 \quad 7 / 22 / 13$ & $\square$ AGR-3/4 Modeling \\
\hline AGR-5/6 Modeling & $4 / 19 / 13 \quad 4 / 9 / 15$ & $\square$ AGR-5/6 Modeling \\
\hline AGR-7/8 Modeling & 6/17/13 5/26/17 & $\square$ AGR-7/8 Modeling \\
\hline GIFVHTR Benchmarking & 10/5/11 9/30/14 & $\square$ GIFVHTR Benchmarking \\
\hline Special Fuel Studies & $4 / 1 / 08 \quad 2 / 6 / 19$ & $\square$ Special Fuel Studies \\
\hline $\begin{array}{l}\text { Fission Product Transport and Source } \\
\text { Term }\end{array}$ & $10 / 1 / 03 \quad 3 / 1 / 22$ & $\begin{array}{l}\text { Fission Product Transport and } \\
\text { Source Term }\end{array}$ \\
\hline FPT and Source Term Planning FY03-FYO8 & $10 / 1 / 03 \quad 10 / 1 / 08$ & FPT and Source Term Planning FY03-FYO \\
\hline Measure Sorption on Matrix and Graphite & $1 / 3 / 11 \quad 3 / 5 / 20$ & $\square$ Measure Sorption on Matrix and Graphite \\
\hline Gas Loop Testing & 10/3/11 12/20/21 & $\square$ Gas Loop Testing \\
\hline Vented Low-Pressure Containment & $10 / 1 / 12 \quad 2 / 1 / 16$ & $\square$ Vented Low-Pressure Containment \\
\hline H-3 Permeabilities of HX Metals & $7 / 5 / 10 \quad 7 / 4 / 11$ & $\square$ H-3 Permeabilities of HX Metals \\
\hline $\begin{array}{l}\text { FPT and Source Term Data Qualification } \\
\text { and Analysis }\end{array}$ & 10/1/08 $\quad 3 / 1 / 22$ & 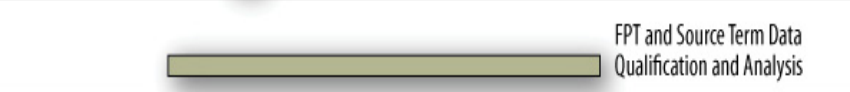 \\
\hline Supporting Activities & $1 / 12 / 09 \quad 6 / 20 / 22$ & Supporting Activities \\
\hline NRC Reports & 9/9/13 6/20/22 & NRC Reports \\
\hline Fuel Fabrication Commercialization & $1 / 12 / 09 \quad 4 / 26 / 17$ & $\square$ Fuel Fabrication Commercialization \\
\hline $\begin{array}{l}\text { Key Milestone 1: Preliminary NRC Topical } \\
\text { on Fuel Performance } \\
\text { (AGR-1 PIE and AGR-2 Irradiation) }\end{array}$ & 9/24/13 & $\begin{array}{l}\text { Key Milestone 1: Preliminary NRC Topical on } \\
\text { Fuel Performance (AGR-1 PIE and AGR-2 Irradiation) }\end{array}$ \\
\hline $\begin{array}{l}\text { Key Milestone 2: Final NRC Topical on } \\
\text { Fuel Performance (AGR 3,4,5 and 6) }\end{array}$ & 12/20/18 & $\begin{array}{l}\text { Key Milestone 2: Final NRC Topical on } \\
\text { Fuel Performance (AGR3,4,5 and 6) }\end{array}$ \\
\hline Key Milestone 3: VHTR Source Term Validated & $6 / 20 / 22$ & Key Milestone 3:VHTR Source Term Validated \\
\hline $\begin{array}{l}\text { Key Milestone 4: Fuel Performance Model } \\
\text { Validated }\end{array}$ & $8 / 17 / 18$ & Key Milestone 4: Fuel Performance Model Validated \\
\hline
\end{tabular}

Figure 1. AGR schedule (continued). 


\section{PRISMATIC FUEL OPTION: B\&W}

\subsection{Fabrication}

The approach to fabrication of the first core mimics that developed in the original acquisition study. There are four major fabrication activities: (1) update the existing pilot facility to improve throughput (parallel lines, extra coater, etc), (2) use this pilot facility to start making fuel for the first core,

(3) concurrently build the production facility, install equipment and perform system checkout, and

(4) transition staff to the new production facility and complete fabrication of the first core.

Currently B\&W can fabricate UCO kernels at an industrial scale. B\&W have fabricated UCO and $\mathrm{UO}_{2}$ particles in a six-inch production scale coater for the AGR-2 performance demonstration irradiation. Current activities are aimed at improving yield and quality of the product. Scale-up of matrix preparation, over-coating and compacting technologies is currently underway. Significant progress has been made to industrialize each of the process steps, maximize yield, and improve product quality all with the aim of meeting the high level of throughput needed in a fuel fabrication facility.

\subsection{Fuel Qualification and Proof Testing}

The prismatic fuel qualification approach builds on the existing AGR program, primarily the AGR-5/6 irradiation, PIE, and testing. These data will be augmented by proof testing, taking representative fuel off the production line, and undergoing irradiation and accident proof testing to confirm that the fuel behavior for fuel off the production line is similar to that found in AGR-5/6. The AGR-5/6 fuel will be fabricated using pilot line equipment and procedures for kernels, coatings and compacts.

\subsection{Schedule}

The updated schedule for the fuel fabrication facility is based upon B\&W plans from the original fuel acquisition study. It assumes that a fabrication facility will be constructed once DOE approves the NGNP project to go into Phase II, preliminary design, and a public/private partnership is established.

Consequently, a start date of October 2012 is assumed. This delays that activity about 5 years from the schedule in the original acquisition strategy so that the first core completes in 2020. Schedule is show in Figure 2. Fabrication of the first core is done in parallel with proof testing. There is no conflict with AGR program work because the proof testing is after AGR-7/8 completes. First core fabrication completes in early 2020 and qualification testing completes in September 2021. The original fissionproduct transport activity from the AGR schedule in Figure 1 will determine the critical path late in the program with completion scheduled for middle of 2022.

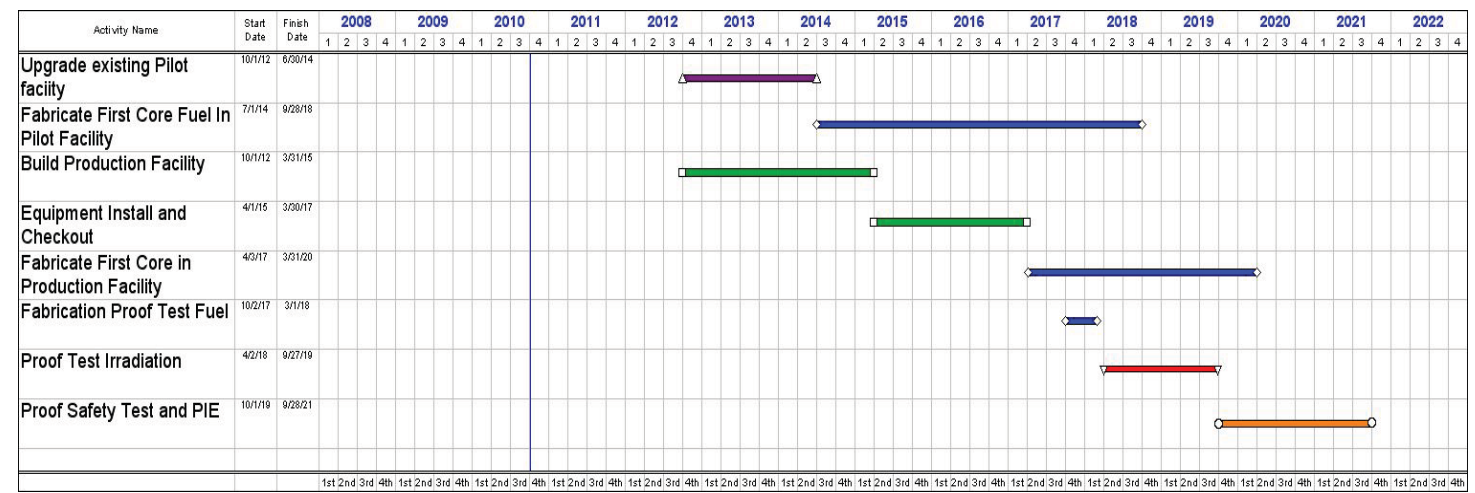

Figure 2. Schedule for B\&W prismatic fuel fabrication and qualification. 


\section{PEBBLE FUEL OPTIONS}

Three options for production of pebble bed fuel are considered in this section. Two options involve LEU $\mathrm{UO}_{2}$ fuel produced by NFI and B\&W that meet German product specifications for TRISO fuel fabricated in the late 1980s. The third involves use of the LEU UCO TRISO particles under development by the AGR fuel program and produced by B\&W. Since the fuel qualification approach is essentially the same for all three options, it is addressed first.

\subsection{Fuel Qualification Approach}

The approach to fuel qualification is essentially the same for all three pebble fuel options, with the exception that the pebble test train containing designed-to-fail (DTF) particles discussed below would not be necessary for the B\&W UCO option because parallel work being done on the prismatic side in AGR 3/4 and AGR 5/6 would be considered applicable.

A performance demonstration of pebbles from early fuel fabrication will increase confidence in the formal qualification testing. Five standard pebbles and five pebbles containing 0.5 to $1 \%$ DTF particles will be irradiated in two standard pebble test trains in the High Flux Reactor (HFR) in Petten, Netherlands using the standard mixture of helium and neon to control temperature and a small amount of hydrogen, carbon monoxide and water vapor to simulate a standard gas reactor coolant environment. The DTF capsule will confirm the release characteristics of failed TRISO $\mathrm{UO}_{2}$ particles performed by the Germans in FRJ2-P28. Following irradiation, one standard pebble would undergo destructive PIE and the remaining four standard pebbles would undergo heat-up testing. For the DTF pebbles, one pebble would undergo destructive examination to establish the retentiveness of the pebble matrix to confirm that the graphitic matrix is as retentive as the historic German matrix, and four pebbles will be used for moisture testing. This work will be done in parallel with the early activities associated with production of the first core of pebbles.

The formal qualification testing will be aimed at validating the failure fraction versus temperature curve used in the PBMR safety analyses. Differences in fuel fabrication equipment and procedures relative to the German fuel production means more extensive irradiation and safety testing will be required to qualify fuel than in the PBMR case where replicated German procedures and equipment were to be used. Based on statistical considerations in Appendix A, it is assumed that 20 pebbles would be needed for irradiation testing, with five pebbles for heat-up testing at $1600^{\circ} \mathrm{C}$ and five at $1700^{\circ} \mathrm{C}$. Fewer pebbles will be needed at $1800^{\circ} \mathrm{C}$ because the diffusional fission-product release and degradation of the $\mathrm{SiC}$ layer of intact particles anticipated at this high temperature reduce the relative importance of particle failures and the corresponding need for statistical demonstration of failure fractions. Three pebbles are assumed for the $1800^{\circ} \mathrm{C}$ testing.

Thus, the formal qualification irradiation would consist of four sets of five pebble irradiations (two at a time) in the HFR in Petten. (While Petten could handle three or four irradiations in parallel, this would not accelerate the schedule given the more limited throughput capability for heat-up testing at ITU Karlsruhe that is required following irradiation.) It is anticipated that the irradiations would be less than 18 months based on the duration of a similar irradiation, EU-1bis, which took 250 effective full power days (EFPDs). Heat-up testing on 13 pebbles should be achievable in about four years based on historical estimates of pebble heat-up testing in Germany. (For the early performance demonstration, one year for heat-up testing is considered adequate.)

The use of Petten and ITU is based on their experience in irradiation and testing pebbles. They have capsule designs that will work, and they have an infrastructure in place within the EU program. This is the most expeditious and cost-effective solution to carrying out two programs in parallel. Some upgrades are anticipated at both Petten and ITU to execute this strategy. 


\subsection{Japanese/NFI TRISO $\mathrm{UO}_{2}$}

\subsubsection{Fabrication}

This approach leverages the existing experience at NFI in Japan to make TRISO-coated $\mathrm{UO}_{2}$ particles. NFI has made TRISO-coated $\mathrm{UO}_{2}$ for the HTTR first and second cores. However, the particle design is slightly different from the German $\mathrm{LEU} \mathrm{UO}_{2}$ design and the particles were formed into annular cylindrical compacts instead of spheres. Fabrication of the second core for HTTR was completed by 2006, but the facility has been idle since that time. NFI's ability to develop the capability to fabricate fuel meeting the German TRISO $\mathrm{UO}_{2}$ particle specification is not in question. The key question is "how long will it take them to manufacture high-quality, low-defect fuel meeting the in-service performance requirements and at what cost?" The SiC defect fraction for the HTTR second core fabricated by NFI and the in-service failure fractions from their historical irradiation and safety testing would not meet anticipated pebble bed specifications. Beyond fabrication of particles, additional process development is required to learn how to fabricate pebbles and develop a capability to fabricate multiple pebbles at a time with a multi-pebble press. In addition, there are a number of regulatory, logistical, and legal concerns, many of which were raised in the original NGNP fuel acquisition strategy report ${ }^{1}$, that question the viability of this option.

\subsubsection{Schedule}

The schedule for this option is in Figure 3. Consistent with other options, the projected start date is October 2012. Based on U.S. experience, it will take about 2.5 years to finish the process development and complete any needed facility upgrades associated with fabrication of TRISO $\mathrm{UO}_{2}$ fuel pebbles meeting German specifications and capable of meeting pebble fuel performance requirements. Fabrication of early fuel for performance demonstration activities is planned in 2015. As in the original acquisition strategy, fabrication of first core takes 5 years and completes in 2020. The two sets of qualification irradiations and safety testing occur in series between 2017 and 2022. Completion is expected by middle of 2022 .

\begin{tabular}{|c|c|c|c|c|c|c|c|c|c|c|c|c|c|c|c|c|c|c|c|c|c|c|c|c|c|c|c|c|c|c|c|c|c|c|c|}
\hline \multirow{2}{*}{ Activity Name } & \multirow{2}{*}{ Start Date } & \multirow{2}{*}{ Finish Date } & \multicolumn{2}{|c|}{2010} & \multicolumn{3}{|c|}{2011} & \multicolumn{2}{|c|}{2012} & \multicolumn{2}{|c|}{2013} & \multicolumn{3}{|c|}{2014} & \multicolumn{3}{|c|}{2015} & \multicolumn{3}{|c|}{2016} & \multicolumn{2}{|c|}{2017} & \multicolumn{3}{|c|}{2018} & \multicolumn{2}{|c|}{2019} & \multicolumn{3}{|c|}{2020} & \multicolumn{2}{|l|}{2021} & \multicolumn{3}{|c|}{2022} \\
\hline & & & \begin{tabular}{|l|l|}
1 & 2 \\
\end{tabular} & $\begin{array}{ll}34 \\
\end{array}$ & 1 & 23 & $\begin{array}{ll}3 & 4 \\
\end{array}$ & $\begin{array}{ll}12 \\
\end{array}$ & \begin{tabular}{|l|l|}
3 & 4 \\
\end{tabular} & \begin{tabular}{l|l|l}
1 & 2 & 3 \\
\end{tabular} & \begin{tabular}{l|l}
3 & 4 \\
\end{tabular} & 1 & 23 & 4 & \begin{tabular}{l|l|l}
1 & 2 & 3 \\
\end{tabular} & \begin{tabular}{l|l}
3 & 4 \\
\end{tabular} & 41 & 23 & $\begin{array}{ll}3 & 4 \\
\end{array}$ & 1 & 2 & \begin{tabular}{|l|l|}
3 & 4 \\
\end{tabular} & 1 & \begin{tabular}{|l|l|}
2 & 3 \\
\end{tabular} & 841 & 12 & \begin{tabular}{l|l}
3 & 4 \\
\end{tabular} & 1 & $2 \quad 3$ & 4 & \begin{tabular}{l|l|l}
1 & 2 & 3 \\
\end{tabular} & 4 & & & 4 \\
\hline $\begin{array}{l}\text { NFI Compacting and Facility } \\
\text { Upgrades }\end{array}$ & 10/1/12 & $3 / 30 / 15$ & & & & & & & & & & & & & & & & & & & & & & & & & & & & & & & & & \\
\hline $\begin{array}{l}\text { Fabricate NFI Trial } \\
\text { Production Fuel }\end{array}$ & $4 / 1 / 15$ & $9 / 29 / 15$ & & & & & & & & & & & & & & & & & & & & & & & & & & & & & & & & & \\
\hline $\begin{array}{l}\text { NFI Fabricate First Core } \\
\text { Load }\end{array}$ & $10 / 1 / 15$ & $9 / 30 / 20$ & & & & & & & & & & & & & & & & & & & & & & & & & & & & & & & & & \\
\hline Fabrication Proof Test Fuel & $7 / 1 / 16$ & $12 / 30 / 16$ & & & & & & & & & & & & & & & & & & & & & & & & & & & & & & & & & \\
\hline $\begin{array}{l}\text { Performance Demonstration } \\
\text { (Petten) }\end{array}$ & $10 / 1 / 15$ & $3 / 31 / 17$ & & & & & & & & & & & & & & & & & & & & & & & & & & & & & & & & & \\
\hline $\begin{array}{l}\text { Safety Test and PIE } \\
\text { Performance Demonstration }\end{array}$ & $4 / 3 / 17$ & $4 / 3 / 18$ & & & & & & & & & & & & & & & & & & & & & & & & & & & & & & & & & \\
\hline $\begin{array}{l}\text { Proof Test Irradiation (Petten } \\
\text { - first set) }\end{array}$ & $1 / 2 / 17$ & $7 / 2 / 18$ & & & & & & & & & & & & & & & & & & & & & & & & & & & & & & & & & \\
\hline $\begin{array}{l}\text { Proof Safety Test and PIE } \\
\text { (first set) }\end{array}$ & $7 / 2 / 18$ & $6 / 29 / 20$ & & & & & & & & & & & & & & & & & & & & & & & & & & & & & & & & & \\
\hline $\begin{array}{l}\text { Proof Test Irradiation (Petten } \\
\text { - second set) }\end{array}$ & $7 / 2 / 18$ & $12 / 30 / 19$ & & & & & & & & & & & & & & & & & & & & & & & & & & & & & & & & & \\
\hline $\begin{array}{l}\text { Proof Safety Test and PIE } \\
\text { (second set) }\end{array}$ & $7 / 1 / 20$ & $6 / 21 / 22$ & & & & & & & & & & & & & & & & & & & & & & & & & & & & & & & & & \\
\hline
\end{tabular}

Figure 3. NFI pebble option schedule. 


\section{$5.3 \quad$ U.S./B\&W TRISO $\mathrm{UO}_{2}$}

\subsubsection{Fabrication}

$\mathrm{B} \& \mathrm{~W}$ can fabricate $\mathrm{UO}_{2}$ TRISO particles meeting German particle specifications (as demonstrated in AGR-2). There is a need to develop pebble fabrication capability at B\&W with support from Oak Ridge National Laboratory (ORNL). Much of the matrix preparation, overcoating, and compacting process development underway for the prismatic option is applicable to pebble fabrication and has potential for substantial improvements relative to the German process. ${ }^{e}$ Four major fabrication activities parallel the prismatic option: (1) update the existing pilot facility to improve throughput (parallel lines, extra coater, etc.), (2) use this pilot facility to start making first core, (3) in parallel build the production facility, install equipment, and perform system checkout, and (4) transition staff to new production facility and complete fabrication of the first core.

\subsubsection{Schedule}

The schedule for this option is in Figure 4. As with the other options, a start date of October 2012 is assumed. It takes two years to learn the process to manufacture pebbles and scale up for first-core production. Fuel fabrication for the performance demonstration activities takes place in 2014. Construction of the production fuel facility and installation and checkout of equipment will take 3.5 years. For the qualification testing, fuel is taken off the pilot line for the first series of qualification tests and taken off the production line for the second series of qualification tests. This approach is necessary to have a reasonable schedule. First core completes in 2021. Fuel qualification testing activities complete in 2022.

\footnotetext{
${ }^{\mathrm{e}}$ There are three key aspects of the overall production of spheres: (a) overcoating, (b) pressing the fuel and then the fuel free zone, and (c) heat treatment and carbonization. Overcoating of the particles is envisioned to leverage the existing work being done using fluidized bed overcoating for commercial application in compact production by B\&W with substantial support from ORNL. For the pebble, the lower packing fractions (10 to $15 \%$ vs. 40 to $50 \%$ for compacts) would require a thicker overcoat. Tests will be conducted using the fluidized bed overcoater at B\&W to demonstrate thicker overcoats. The use of the fluidized bed overcoater to produce uniform thickness overcoats to achieve packing fractions in the 10 to $15 \%$ range would eliminate the need for additional matrix. Mixing additional matrix, as required in the German process, produces non-uniformities in the particle distribution and a higher potential for particle-to-particle contact during pressing. The pressing work would be done at ORNL using a "single pebble" press with support from INL and B\&W (Since NFS is also now owned by the B\&W parent company, the pressing capability from NFS could be utilized to reduce costs and accelerate the schedule for the overall program). While the Germans did much of their pressing at room temperature, the successful work done so far with compacts suggests warm/hot pressing is worth considering for pebbles as well. Warm pressing may be preferred because of longer thermal time constant in the large sphere compared to the compact. The mold material would require development to support warm pressing. In parallel, a multi-pebble press would need to be designed fabricated and tested at B\&W to demonstrate adequate throughput. During the testing at $\mathrm{B} \& \mathrm{~W}$ there may need to be iterations with ORNL if parameters do not transfer exactly from the single press to the multi-press. Pressing of the sphere will of course be different than the compact, especially the addition of the fuel free zone on the outside of the pebble. Heat treatment and carbonization are basically the same for pebbles and compacts. The only difference may be slower ramp rates to temperature because of larger compact size.
} 


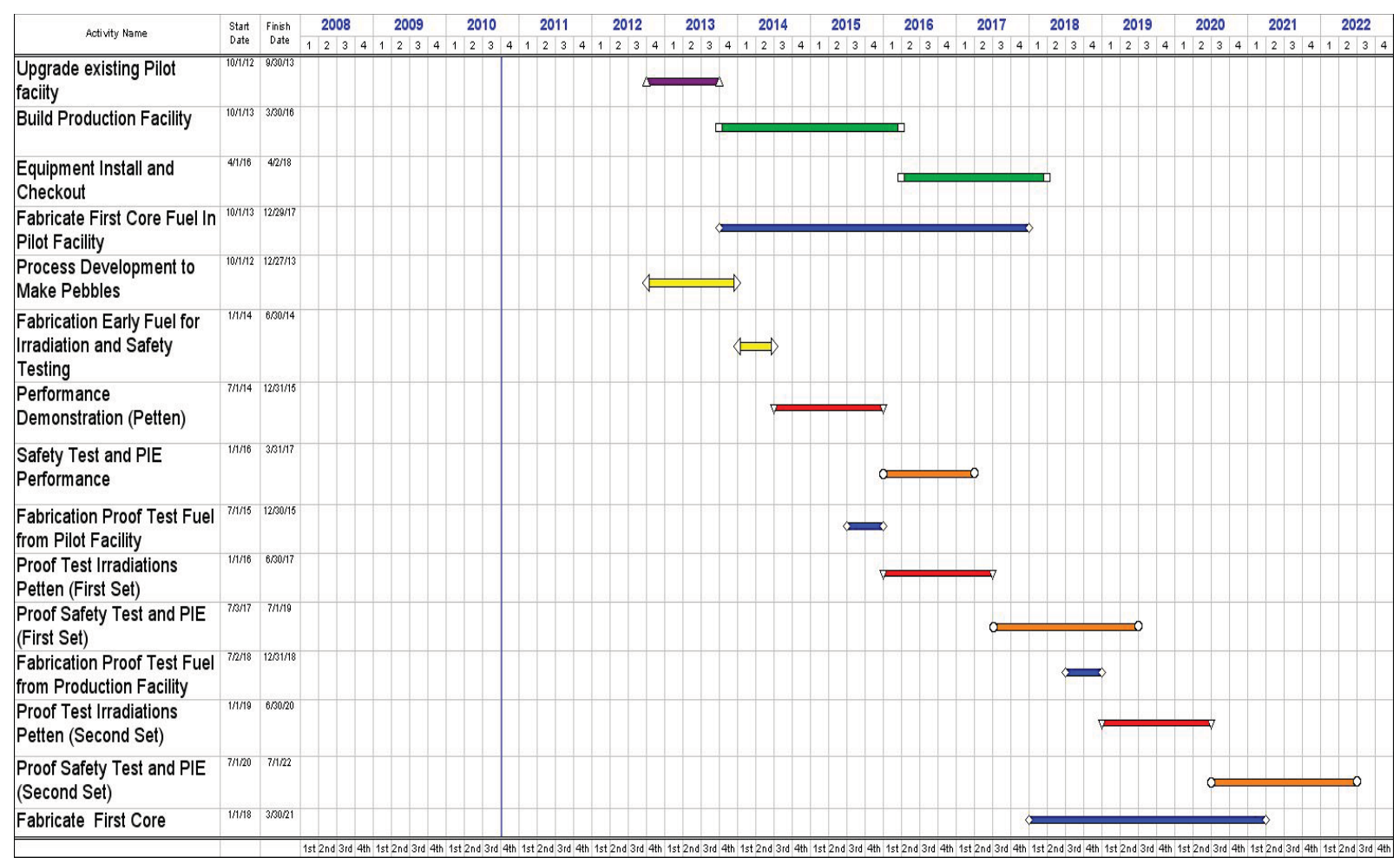

Figure 4. B\&W pebble option schedule in calendar years and quarters.

\subsection{U.S./B\&W UCO}

While historically all pebble bed power reactor designs have used TRISO $\mathrm{UO}_{2}$ particles in the pebble, TRISO UCO particles could be used. In the course of AVR operation over 5,000 spheres with highly enriched uranium (HEU) $\mathrm{UCO} / \mathrm{ThO}_{2}$ fuel were loaded into the reactor. The higher enrichment and higher burnup associated with UCO being qualified for the prismatic option could be quite attractive for the pebble bed given that higher burnup translates into enhanced fuel utilization and improved reactor plant economics. The pebble UCO option also results in less potential disruption to the existing NGNP/AGR program.

\subsubsection{Core Design}

Preliminary scoping calculations have been performed to examine the feasibility of using the $14 \%$ enriched 425-micrometer UCO particle being qualified for the prismatic option. ${ }^{4}$ The analysis compared the coupled neutronic and thermal fluid performance of the HTR Module fueled with $7.8 \%$ enriched $\mathrm{UO}_{2}$ and with $14 \%$ enriched UCO. Several UCO cases were investigated involving different sphere heavy metal loadings and recirculation rates.

Additional work would be required to arrive at a core design that is optimized for the higher enriched UCO fuel. This would involve a trade-off of core design objectives including peaking factors, discharge burnup, normal operation and accident temperature conditions, control rod worths, etc. The results of the scoping study demonstrated the feasibility of utilizing the higher enriched UCO fuel. The analysis results showed that the dominant contributor to the observed differences between the HTR Module $\mathrm{UO}_{2}$ and UCO cores is the increase in the ${ }^{235} \mathrm{U}$ enrichment to $14 \%$, and not the additional moderation effects of the oxygen-to-carbon exchange. 


\subsubsection{Fabrication, Qualification, and Schedule}

The fabrication and qualification tasks for this option are identical to that of the $\mathrm{B} \& \mathrm{~W} \mathrm{UO}_{2}$ option outlined in Section 5.2. However, there is no need for the DTF pebble irradiation and associated moisture testing. The parallel work being done in the prismatic elements of the program in AGR 3/4 and AGR 5/6 would be considered applicable. As a result, there will be cost savings, but since the development irradiations and safety testing are not critical path, the schedule outlined in Section 5.2 is also applicable.

\subsection{Cost Considerations}

In the near term, executing fuel qualification activities for both concepts will be difficult both in terms of manpower and funding. To have any of these options complete in the 2022 time frame will require significant increases in funding over the \$25-30M that the AGR program has been receiving in the past few years. Furthermore, there are activities identified in the latest version of the program plan related to moisture and air ingress testing and fission-product transport out-of-pile loop testing that need to be funded in FY 2011 and FY 2012 in order to ensure the schedule is maintained.

A rough estimate of the cost to carry out the fuel qualification activities identified in the pebble options is provided below in Table 5. Costs associated with building the production line and producing first-core fuel are not included. They are part of the NGNP construction cost. The estimates are based on experience in the AGR program to date.

- Fabrication: $\$ 11 \mathrm{M}$ for process development, facility upgrades, and production of early fuel and DTF pebbles.

- Irradiation: $\$ 5 \mathrm{M}$ for infrastructure (anticipate some upgrades needed to irradiate two test trains simultaneously and to test under helium-neon mixtures with representative impurities and $\$ 6 \mathrm{M}$ per test train. (Test train designs already exist. Costs are associated with fabrication of the test train, safety paperwork, and experiment monitoring.)

- Shipping: \$1.5M/experiment.

- PIE (disassembly, metrology, and ceramography) at Petten: \$1M in upgrades; \$3M/experiment.

- Heat-up testing at ITU: $\$ 5 \mathrm{M}$ to get moisture system operational at ITU, $\$ 1 \mathrm{M}$ to get furnace system ready, plus $\$ 5 \mathrm{M} /$ year for heat-up testing, plus $\$ 3 \mathrm{M}$ for moisture testing.

Table 5. Estimated additional cost to implement fuel qualification activities for either pebble option on top of prismatic option alone.

\begin{tabular}{|c|c|c|c|c|}
\hline Activity & Upgrades & $\begin{array}{c}\text { Performance } \\
\text { Demonstration }\end{array}$ & $\begin{array}{l}1^{\text {st }} \text { Series Fuel } \\
\text { Qualification }\end{array}$ & $\begin{array}{c}2^{\text {nd }} \text { Series Fuel } \\
\text { Qualification }\end{array}$ \\
\hline Fuel Fabrication & 5 & 6 & & \\
\hline Irradiation & 5 & 12 & 12 & 12 \\
\hline Shipping & & 3 & 3 & 3 \\
\hline PIE & 1 & 6 & 6 & 6 \\
\hline Heat-up Testing & 6 & 8 & 10 & 10 \\
\hline Technical Support and Integration & 1 & 1.5 & 2 & 2 \\
\hline TOTAL & $18^{\mathrm{a}}$ & $36.5^{\mathrm{a}}$ & $33^{\mathrm{a}}$ & $33^{\mathrm{a}}$ \\
\hline
\end{tabular}


The total cost to take either $\mathrm{UO}_{2}$ option to completion is $\$ 120.5 \mathrm{M}$. The B\&W UCO pebble option would be about $\$ 9 \mathrm{M}$ less because some of the data can be obtained from the prismatic fuel testing. If the cost is spread equally over the next decade, it would require approximately $\$ 12 \mathrm{M}$ per year to be added to the current $\$ 25-30 \mathrm{M}$ per year baseline AGR program. However, the current schedule envisions a decision around 2015 at which point additional expenditure for pursuing both pebble bed and prismatic options will be roughly $\$ 40 \mathrm{M}$.

\subsection{Recommendations on Pebble Bed Options}

For each of the pebble options, the risks associated with fuel acquisition are discussed in terms of the following criteria: fuel plant licensing, fuel manufacturing process, facility capacity, transportation, and funding/intellectual property issues. For each option, the risk is categorized in Table 6 as high, medium or low. The sections below discuss the rationale for the risk ranking.

Table 6. Summary of risk of pebble bed options

\begin{tabular}{|l|c|c|c|}
\hline Risk Criteria: Definition & $\begin{array}{c}\mathrm{NFI} \\
\mathrm{UO}_{2}\end{array}$ & $\begin{array}{c}\mathrm{B \& W} \\
\mathrm{UO}_{2}\end{array}$ & $\begin{array}{c}\mathrm{B} \& W \\
\mathrm{UCO}\end{array}$ \\
\hline $\begin{array}{l}\text { Fuel Plant Licensing: Concern about issues associated with the } \\
\text { license needed to fabricate the first and follow-on cores }\end{array}$ & Med & Low & Low \\
\hline $\begin{array}{l}\text { Fuel Manufacturing Process: Concern about ability to meet } \\
\text { specification }\end{array}$ & High & Low & Low \\
\hline $\begin{array}{l}\text { Facility Capacity: Concern about the facility's ability to make the } \\
\text { requisite amount of fuel in the allotted schedule }\end{array}$ & Low & Low & Low \\
\hline $\begin{array}{l}\text { Transportation: Concern about the risks associated with shipping of } \\
\text { fuel to NGNP site including cask licensing, import/export issues, } \\
\text { taxation for foreign supplies etc. }\end{array}$ & Med & Low & Low \\
\hline $\begin{array}{l}\text { Funding/Intellectual Property Rights: Concern about sources of } \\
\text { funding for process development and facility modifications and } \\
\text { access to intellectual property that is generated }\end{array}$ & High & Low & Low \\
\hline \multicolumn{1}{|c|}{ Overall Risk } & Med & Low & Low \\
\hline
\end{tabular}

\section{Fuel Plant Licensing}

$\mathrm{B} \& \mathrm{~W}$ is currently licensed to handle a variety of both HEU and LEU fuels. Based on B\&W prior experience with nuclear fuels, there is low risk associated with their ability to obtain a license for the production plant.

The NFI facility is currently licensed as a research facility at a production level up to $400 \mathrm{kgU} / \mathrm{year}$. A limited relicensing within the research facility framework, in conjunction with limited facility modifications, would support production at the level needed for the pebble bed.

\section{Fuel Manufacturing Process}

$\mathrm{B} \& \mathrm{~W}$ has demonstrated the capability to fabricate $\mathrm{UO}_{2}$ and UCO TRISO fuel particles with defect levels that approach NGNP requirements. Process development would be required to fabricate pebbles. However, the ability to leverage the current process development for matrix preparation, overcoating and compacting provides confidence and reduces the risk associated with mastering pebble fabrication.

Although the actual NFI fuel quality has been much better than the HTTR specifications (which are much less restrictive than current NGNP specifications), the quality of the second core of HTTR (e.g., 
SiC defects) would not meet anticipated NGNP specifications. In addition, process development would be required for NFI to produce particles to the NGNP specifications and to fabricate pebbles.

\section{Facility Capacity}

For all options, quantities of fuel required for first core are modest and achievable within the schedule.

\section{Transportation}

Shipping containers for use in the U.S. have recently been certified for use with irradiated TRISO fuel and thus containers to ship unirradiated pebbles could be developed. Shipping internationally will present more challenges (e.g., export license from Japan, import license from U.S., multiple approvals by agencies required by the U.S., taxation of enriched uranium).

\section{Funding/Intellectual Property Rights}

The B\&W options would be completely funded by U.S. DOE. Hence, DOE would retain all property rights, consistent with existing contractual agreements.

Funding sources for process development and facility upgrades for production for fuel by NFI are not currently established. The issues associated with retention of intellectual property, ownership of facilities, and funding sources are not defined at this point. The establishment of a non-U.S. fuel vendor for NGNP is inconsistent with the requirement to support the U.S. nuclear infrastructure in the U.S. Energy Policy Act of 2005 .

\section{Recommendations}

Based upon this assessment, the ranking of pebble options in order of preference is as follows:

- B\&W UCO TRISO because it leverages the significant effort expended already on UCO. It is less expensive than the other options, less disruptive to the overall program, and offers higher performance for the pebble bed because of the higher burnup achievable with UCO.

- $\mathrm{B} \& \mathrm{~W} \mathrm{UO} \mathrm{U}_{2}$ TRISO because it requires about the same amount of fabrication development as the $\mathrm{B} \& \mathrm{~W}$ UCO TRISO option.

- $\quad \mathrm{NFI} \mathrm{UO} \mathrm{U}_{2}$ TRISO is the lowest priority because of the issues associated with using a foreign fuel vendor including export control, intellectual property, and moderate risk associated with meeting the NGNP specification. Further, this option does not establish a viable U.S. fuel vendor. 


\section{REFERENCES}

1. Petti, David, Tim Abram, Ben Franklin, Richard Hobbins, and Jim Kendall, 2007, Assessment of Next Generation Nuclear Plant (NGNP) Fuel Acquisition Strategies, INL/EXT-07-12441, Rev 1, October 2007.

2. NRC Fuel Qualification White Paper, INL/EXT-10-17686, July 2010.

3. Technical Program Plan for the Next Generation Nuclear Plant/Advanced Gas Reactor Fuel Development and Qualification Program, PLN-3636, September 30, 2010.

4 Gerhard Strydom, "Reactor Physics Characterization of the HTR Module with UCO Fuel, "I INL/EXT-10-20251, Revision 0, November 12, 2010 
Appendix A

Statistical Considerations Associated with Irradiation and Testing of Pebble Fuel 


\section{Appendix A}

\section{Statistical Considerations Associated with Irradiation and Testing of Pebble Fuel}

Since the pebble fuel acquisition options do not include replication of the German high quality LEU $\mathrm{UO}_{2}$ fuel fabrication equipment and processes, it is assumed that the German fuel test data will not be directly applied in the demonstration of failure fractions for the pebble fuel. However, all of the options draw heavily from the German experience and are generally directed toward replication of the German coating process conditions and properties. Thus, the amount of fuel required for testing can be based on projections for particle failures experienced during irradiation and testing derived from the German fuel test data.

The expected failure fractions are assumed to be consistent with the data in Table 13 of INL/EXT-1017686, "NGNP Fuel Qualification White Paper". An estimate of the number of spheres needed for irradiation and heating tests can be developed by assuming that the number of particle failures observed from German testing is consistent with the $50 \%$ failure probability projections. Then using the results to demonstrate that the $95 \%$ failure probability failure fractions are consistent with the projected values, that form the basis for safety analysis methods. Two cases regarding the numbers of particle failures observed in the tests were considered (see Table A-1):

- Case 1. The failure fractions observed in the irradiation and heating tests exactly matched the $50 \%$ confidence values.

- Case 2. The number of failures determined in Case 1 is increased by a factor of 1.1 plus two additional particle failures (the additional failures add margin in cases with very low failure probabilities).

Table A-1. The relevant data from Table 13 and the calculational results are summarized below (number of spheres assumes 11,200 particles/sphere).

\begin{tabular}{|c|c|c|c|c|c|c|}
\hline \multicolumn{3}{|c|}{$\begin{array}{l}\text { Failure fraction values from Table 13, } \\
\text { pg. } 63 \text { of Fuel Qualification white paper }\end{array}$} & \multicolumn{4}{|c|}{$\begin{array}{c}\text { Minimum Number Spheres/Expected Number } \\
\text { Failed Particles }\end{array}$} \\
\hline \multirow[t]{2}{*}{ Temperature } & \multirow[t]{2}{*}{$\begin{array}{c}\text { NGNP } \\
\text { Expected }\end{array}$} & \multirow[t]{2}{*}{$\begin{array}{l}\text { NGNP 95\% } \\
\text { Confidence }\end{array}$} & \multicolumn{2}{|c|}{$\begin{array}{c}\text { Case } 1 \\
50 \% \text { Confidence }\end{array}$} & \multicolumn{2}{|c|}{$\begin{array}{c}\text { Case } 2 \\
1.1 \times 50 \%+2 \text { part }\end{array}$} \\
\hline & & & \# spheres & \# part. & \# spheres & \# part. \\
\hline $800-1200$ & $1.44 \mathrm{E}-05$ & $4.88 \mathrm{E}-05$ & 13 & 2 & 25 & 7 \\
\hline 1600 & $2.08 \mathrm{E}-04$ & $4.11 \mathrm{E}-04$ & 3 & 6 & 6 & 17 \\
\hline 1700 & $6.12 \mathrm{E}-04$ & $9.31 \mathrm{E}-04$ & 3 & 16 & 6 & 42 \\
\hline 1800 & $1.85 \mathrm{E}-03$ & $2.21 \mathrm{E}-03$ & 5 & 86 & & \\
\hline
\end{tabular}

The number of spheres at $1800^{\circ} \mathrm{C}$ are affected by the relatively low ratio between the $95 \%$ and $50 \%$ confidence values in the table, with this ratio decreasing from 3.4 in the normal operation range to $2,1.5$, and 1.2 at 1600,1700 , and $1800^{\circ} \mathrm{C}$. The result becomes totally unrealistic for Case 2 . Assuming the fuel behaves like the German fuel, metallic releases for the $1800^{\circ} \mathrm{C}$ case will be dominated by corrosion of and diffusion through the silicon carbide layers of intact particles. Also, in the German $1800^{\circ} \mathrm{C}$ test data, the gas release trends do not indicate sudden particle failures, so failure fraction is not a meaningful metric at this high temperature. Thus, at this high temperature the number of spheres should be based on demonstration of repeatability of results rather than a statistical demonstration of failure fractions. 
Given these considerations and calculational results, an irradiation and testing matrix that represents a degree of conservatism relative to the expected failure fractions (Case 1) but less than the assumptions of Case 2 is considered a reasonable balance between requiring an excessive number of spheres and the prospect that the data would be insufficient to demonstrate the assumed $95 \%$ confidence failure fractions. Table A-2 provides the following recommended matrix:

Table A-2. Recommended Matrix.

\begin{tabular}{|c|c|c|}
\hline & Temperature, ${ }^{\circ} \mathrm{C}$ & Number of Spheres \\
\hline Irradiation & $800-1200$ & 20 \\
\hline \multirow{3}{*}{ Heating Tests } & 1600 & 5 \\
\cline { 2 - 3 } & 1700 & 5 \\
\cline { 2 - 3 } & 1800 & 3 \\
\hline
\end{tabular}

This matrix results in seven irradiated spheres not assigned to heating tests, with one or more of those spheres dedicated to destructive methods to determine fuel condition at the end of irradiation and additional spheres for moisture tests and/or heating tests if necessary. Assuming the irradiations are conducted in the HFR reactor at Petten using the test train design associated with the HFR-EU1 irradiation, 5 spheres would be irradiated at a time, requiring a total of four irradiations. For scheduling purposes, it is assumed that two test train are irradiated in parallel. 